\title{
MONETARY POLICY AND PRIVATE SECTOR PERFORMANCE IN NIGERIA
} (1995-2020)

\section{Oyakegha Ekiyeghazi Samuel and Arepo Lookman Adeniyi}

PhD Students Department of Banking and Finance, Niger Delta University, Bayelsa State.

Phone No: 08037046538, E-mail: priyehc@yahoo.com

\section{Cite this article:}

Oyakegha E.S., Arepo L.A. (2022), Monetary Policy and Private Sector Performance in Nigeria (1995-2020). African Journal of Accounting and Financial Research 5(1), 3544. DOI: $10.52589 / A J A F R-$ V2HINPOA

\section{Manuscript History}

Received: 28 July 2021

Accepted: 12 Aug 2021

Published: 22 Feb 2022

Copyright $\odot 2022$ The Author(s). This is an Open Access article distributed under the terms of Creative Commons AttributionNonCommercial-NoDerivatives 4.0 International (CC BY-NC-ND 4.0 ), which permits anyone to share, use, reproduce and redistribute in any medium, provided the original author and source are credited.
ABSTRACT: The study examines the impact of monetary policy on private sector performance in Nigeria; for the period 19952019. Secondary data were used and collected from the Central Bank of Nigeria Statistical Bulletin. The study used Private Sector Output is proxy for Private Sector performance and employed as the dependent variable; whereas, broad money supply, liquidity rate and Credit Ratio respectively were used as the explanatory variables to measure monetary policy. Hypotheses were formulated and tested using time series econometric techniques. The study revealed a significant effect of credit ratio on private sector output in Nigeria. Liquidity ratio had a significant effect on private sector output in Nigeria. Broad money supply had a significant effect on private sector output in Nigeria. Hence, there is a long-run equilibrium effect on monetary policy and the private sector economy in Nigeria; and, the result confirms that about $73 \%$ short-run adjustment speed from long-run disequilibrium. The coefficient of determination indicated that about $65 \%$ of the variations in private sector led-economy can be explained by changes in monetary policy variables. The study concluded that monetary policy had impacted significantly on private sector growth in Nigeria. The study recommended that strong macroeconomic policies should be employed to maintain and stabilize the economy. CBN should lay down strict prudential guidelines to stabilize and strengthen the private sector ledeconomy. Government and policy makers should formulate policies that will increase the flow of investable funds and improves the capacity of private economy.

KEYWORDS: Monetary Policy, Private Sector, Performance, Nigeria 


\section{INTRODUCTION}

The development of private sector in an economy greatly depends on efficient and effective monetary policy instruments (Ajie \& Azuna, 2018). However, over the years, Nigeria has embarked on various monetary policy frameworks such as the prudential guideline, credit ceiling and financial liberalization policy to facilitate growth and development of the private sector led-economy. Hence, study carried out by Chiwendu and Nnorom (2018) revealed that there was an extensive use of direct control measures before the emergence of financial liberalization policy in 1986. Thus, the difficulties encountered under the direct control regime led to the introduction of SAP; subsequently, followed by financial liberalization policy (Andabai, Ikeora \& Anah, 2019). This was one of the measures taken to enable private sectorled economy to develop in Nigeria. Thus, for the real sector to achieve the desired objectives the financial institutions are also expected to provide financial resources in line with policy directives that are put in place by the monetary authorities in the country (Oguda \& Chinda, 2018).

The empirical work conducted by Chineyerem and Burono (2018) stated that the real sector is strategic for growth and development; because, of the following reasons: (i) it produces and distributes goods and services required to satisfy aggregate demand in the economy; (ii) the performance of the private sector can be used to measure the effectiveness of macro-economic policies. This is because, a well performing real sector; particularly agriculture, manufacturing, real estate, trade, oil and gas, construction and communication is expected to contribute positively to the growth and development of the economy. This corroborates the work of Andabai (2017) which indicated a positive significant effect of private sector development and economic growth in Nigeria. Thus, the relevance of the private sector-led economy is also manifested in its capacity building role as well as high employment and income generating potentials for the economy. However, the work carried out by Bernite and Benson (2018) stressed that for these reasons, there is need for adequate credit flow from the financial institutions to the private sector-led economy.

The work of Ofuegbo (2017) posited that in Nigeria monetary policy appears to have some setbacks; because, of inconsistent government policy, inability to implement the formulated policies, political and economic instability, absence of workable long-term development plans, and corruption at all levels of government etc. Study carried out by Agbokhese and Asekone (2016) revealed a positive significant impact of monetary policy on private sector growth in Nigeria; while, the work of Olaife (2017) found a negative significant impact of monetary policy on private sector growth in Nigeria. Hence, some note-able studies such as Ougaku and Oparanta (2018), Obiogbolo (2018) and Leburio (2018) revealed inconsistent significant effect of monetary policy on private sector growth in Nigeria. Therefore, based on these findings; the study concluded that there are no consensus results on the impact of monetary policy on private sector growth in Nigeria. Thus, these conflicting results and problems created a knowledge gap in this study; and, it is against this background that the study attempts to investigate empirically the impact of monetary policy on private sector growth in Nigeria. 


\section{THEORETICAL FRAMEWORK}

This study is anchored on the Keynesian theory of money and prices (1930); which viewed monetary policy instruments as a reward for parting with liquidity (money). This provides interest rate as a determinant of demand and supply of money, hence, the theory indicated that money supply is usually determined by monetary authority which is the central bank; while, the demand for money is a function of income and interest rate. The theory further explains that transactionary and precautionary motives of liquidity preference depends on income, whereas, speculative motive depends on interest rate. Thus, the Keynesian theory implies that low interest rate as a component of cost administered is detrimental to increasing savings; and, hence investment demand. The work of Aliyu and Daida (2018) revealed that the proponents of this theory argued that increase in the real interest rate will have strong positive effect on savings which can be utilized in investment; because, those with excess liquidity will be encouraged to save subject to favourable interest rate. Therefore, banks will have excess money to lend to investors for investment purposes thereby raising the volume of productive investment and increasing their profitability. This theory introduced the concept of liquidity trap, a situation where low interest rate discourages savings and consequently reduces investments due to lack of investable fund (Bellowa \& Amelant, 2017).

\section{EMPIRICAL REVIEW}

Adupo (2017) investigated the determinants of loans and advances in the Nigerian financial system. Liquidity ratio, capital base, bank deposit and lending rates were used to determine their effect on loans and advances. The study reveals that a relationship exists between dependent variable (loans and advances) and independent variables of total deposit, capital base, liquidity ratio, and lending rate.

Ofegbu (2018) conducted a study on the determinant of banks profitability in Nigeria, indicates that banks profitability is largely determined by risk and other factor that relates to the internal organization of banking firm. He further brings to bear that market concentration is a significant determinant of banks profitability. More so, exchange rate was found to be significant as a determinant of bank profitability through return on equity and net-interest margin, but not significant to return on asset (ROA) as a measure of profitability.

Aliyu and Daida (2017) examined the effect of monetary policy on bank performance in Nigeria. Bank rate, inflation rate, and exchange rate are total credit enhancing while liquidity ratio and cash reserve ratio. They further add that monetary policy instruments are not effective to stimulate credit in the long run, while bank total credit is more responsive to cash reserve ratio. Agbokhese and Asekone (2016) appraised the impact of monetary policy on bank credit creation in Nigeria between 1980-2014 found that there was a positive linear relationship between total credit creation and the explanatory variables, total credit creation, total deposit and treasury bill rate while reserve requirement ratio and interest rate had a negative relationship with total credit creation. They further add that any monetary policy by the monetary authorities to control credit that emphasizes on reserve requirement could not be effective as the banks could afford to raise and keep substantial deposit as reserve contrary to the action of the monetary authorities. 
Ekpo and Mustapher (2015) evaluated the effect of bank profitability on the performance of the Nigerian economy. The study examined whether liquidity affects banks profitability in the short run, efficiency of labour only affect banks profitability in the long run but as for the external or macro-economic variable which determines bank profitability, broad money supply was found to be significant at both the long and short run. Fadzlan and Muzafa (2017) conducted a study on the determinant of bank profitability in a developing economy from Bangladesh. Their result indicated that loan intensity, credit risk and cost have positive and significant impact on bank performance, while non-interest income exhibits negative relationship with bank profitability.

\section{METHODOLOGY}

The study employed ex-post-facto research design. Secondary data were used and collected from the Central Bank of Nigeria Statistical Bulletin. Private Sector Output is used as a proxy for Private Sector growth and employed as the dependent variable; whereas, broad money supply, credit ratio and Liquidity ratio respectively are used as the explanatory variables to measure monetary policy as indicated on appendix $\mathbf{1}$.

\section{Model Specification}

Multivariate linear regression model is used to test the null hypotheses formulated for the study. Monetary policy does not have any significant impact on private sector growth in Nigeria. Based on this, a model was adapted from the work of (Ougaku \& Oparanta, 2018) and stated as: $\mathrm{GDP}=f\left(\mathrm{M}_{2}, \mathrm{LQR}, \mathrm{CRR}\right)$

Where: GDP = Gross Domestic Product as proxy for economic growth

$\mathrm{M}_{2}=$ Broad Money Supply, LQR = Liquidity Ratio, CRR= Credit Ratio

The above model is modified in this study by introducing Private Sector Output as proxy for

Gross Domestic Product (GDP) and was employed as the dependent variable. Thus, the modified model is stated as: $\mathrm{PSO}=f\left(\mathrm{M}_{2}, \mathrm{LQR}, \mathrm{CRR}\right)$

Where: PSO = Private Sector Output as proxy for Private Sector growth

$\mathrm{M}_{2}=$ Broad Money Supply, LQR $=$ Liquidity Ratio, CRR $=$ Credit Ratio

Hence, the econometric model can be stated as:

$\mathrm{LnPSO}=\delta_{0}+\mathrm{Ln} \delta_{1} \mathrm{M}_{2}+\mathrm{Ln} \delta_{2} \mathrm{LQR}+\mathrm{Ln} \delta_{3} \mathrm{CRR}+\mu$

$\delta_{0}=$ intercept and $\delta_{1}, \delta_{2}$ and $\delta_{3}$ are the coefficients of the regression equation. 


\section{DATA PRESENTATION AND DISCUSSION}

The study focused on the impact of monetary policy on private sector growth in Nigeria; for the period 1995-2019. The study used Private Sector Output is proxy for Private Sector performance and employed as the dependent variable of the study; whereas, monetary policy rate, liquidity ratio and credit ratio respectively were used as the explanatory variables to measure monetary policy respectively as indicated on appendix $\mathbf{1}$.

Table 1: Descriptive statistics

$\begin{array}{lcccc} & \text { PSO } & \mathrm{M}_{2} & \mathrm{LQR} & \text { CRR } \\ \text { Mean } & 57495.97 & 42542.34 & 24.87546 & 56.57656 \\ \text { Median } & 46467.65 & 52136.50 & 28.47380 & 36.64860 \\ \text { Maximum } & 52147.23 & 77966.45 & 36.33745 & 56.54632 \\ \text { Minimum } & 32167.54 & 36354.28 & 9.250000 & 47.93436 \\ \text { Std. Dev. } & 66748.02 & 148.69 .05 & 5.756590 & 68.18654 \\ \text { Skewness } & 0.6849 .52 & 3.146739 & 1.043526 & 25.99586 \\ \text { Kurtosis } & 3.3859 .32 & 14.19450 & 5.256220 & 26.74247 \\ & & & & \\ \text { Jarque-Bera } & 0.386754 & 218.6463 & 12.83540 & 35.46579 \\ \text { Probability } & 0.746589 & 0.000000 & 0.001612 & 0.243549 \\ \text { Sum } & & & & \\ \text { Sum Sq. Dev. } & 147.3475 & 39945.45 & 253.4000 & 13635.49 \\ & 1253.846 & 463548.4 & 465.1700 & 2867.166 \\ \text { Observations } & 25 & & & \\ \end{array}$

Source: Author's computation with the use of E-view 9.1

The descriptive statistics on table 1 shows that private sector output (PSO) for the period under study had a mean value of $\$ 549,795.97$, monetary policy rate had $\$ 54,542.34$ and liquidity ratio had $28.86 \%$, while credit ratio had $56.57 \%$. The Jarque-Bera statistic shows that two of the variables, namely private sector output and private sector output (PSO) were normally distributed while credit ratio and liquidity ratio were highly skewed. Furthermore, private sector output has a mean of $\$ 4,795.88$ this implies that for the period under review the private sector output was very high; this is because, the monetary policy has impacted significantly on the growth and development of private sector economy in Nigeria.

\section{Unit Root Test}

The stationary test of the variables was done using the Augmented Dicker Fuller (ADF) Unit Root Test. The result on table 2 shows that all the variables are integrated at first difference i.e. $1(1)$ at the $5 \%$ or $1 \%$ level of significance. 
Table 2: Unit Root Tests Analysis

\begin{tabular}{|l|l|l|l|l|}
\hline \multicolumn{1}{|c|}{ Variables } & \multicolumn{1}{c|}{$\begin{array}{c}\text { ADF test } \\
\text { Statistics }\end{array}$} & $\begin{array}{c}\text { Mackinnon } \\
\text { critical V. @ 5\% }\end{array}$ & $\begin{array}{c}\text { No of the time } \\
\text { difference }\end{array}$ & Remark \\
\hline PSO & 4.1536352 & -4.024363 & I(1) & Stationary \\
M2 & -1.0318275 & -6.011248 & I(1) & Stationary \\
LQR & -5.1425643 & -4.213279 & I(1) & Stationary \\
CRR & 3.9375465 & 6.302326 & I(1) & Stationary \\
\hline
\end{tabular}

Notes: (1)1\% level of significance, $5 \%$ level of significance, $10 \%$ level of significance. The tests accepted at 5\% level of significance. Source: Researcher's Estimation using- E-views 9.1.

\section{Test for Co-Integration}

Having found that all the variables are stationary at first difference, the next step is to perform Johansen co-integration procedure to ascertain whether Private Sector Output, broad money supply, liquidity ratio and Credit Ratio are co-integrated in the same order. The results of the test are presented on table 3.

Table 3: Multivariate Johansen's Co-Integration Test Result.

\begin{tabular}{|l|l|l|l|l|l|l|}
\hline $\begin{array}{l}\text { Null } \\
\text { hypotheses }\end{array}$ & $\begin{array}{l}\text { Alternative } \\
\text { hypotheses }\end{array}$ & Eigen value & $\begin{array}{l}\text { Likelihood } \\
\text { ratio }\end{array}$ & $\begin{array}{l}\text { Critical vale } \\
5 \%\end{array}$ & $\begin{array}{l}\text { Critical value } \\
1 \%\end{array}$ & $\begin{array}{l}\text { Hypothesized } \\
\text { No. of CE(s) }\end{array}$ \\
\hline $\mathrm{r}=0$ & $\mathrm{r}=1$ & 0.73644 & 69.26347 & 58.35 & 48.02 & None $* *$ \\
\hline $\mathrm{rd} \leq 1$ & $\mathrm{r}=2$ & 0.63865 & 63.75649 & 43.03 & 36.89 & At most 1 \\
\hline $\mathrm{rd} \leq 2$ & $\mathrm{r}=3$ & 0.56983 & 58.25033 & 33.83 & 28.06 & At most 2 \\
\hline $\mathrm{rd} \leq 3$ & $\mathrm{r}=4$ & 0.46254 & 36.85762 & 28.06 & 24.53 & At most 3 \\
\hline
\end{tabular}

Source: E-views Econometrics 9.1. Note* $(* *)$ denotes rejection of hypothesis at 5\% (1\%) significance level.

\section{Vector Error Correction Model}

The Error Correction coefficient contains information about whether the past values affect the current values of the variable under study and the significant coefficient implies that past equilibrium errors play a role in determining the current outcomes (Ibenta, 2012).

\section{Table 4: Vector Error Correction Estimates Results}

Dependent Variable: PSO

Method: Least Squares, Time: 04:38

Sample: 1990-2018

Included observations: 29

\begin{tabular}{lllll} 
Date: $07 / 03 / 2019$ & Coefficient & Std. Error & t-Statistic & Prob. \\
\hline \hline (ECM)(-1) & -0.824383 & 32.37843 & 12.03083 & -0.000004 \\
D(PSO-1) & 5.364546 & 2.467594 & 1.465784 & 0.000030 \\
D(PSO-2) & 7.476834 & 5.456583 & 2.546859 & 0.000008 \\
C & 4.576485 & 9.465785 & 3.875696 & 0.000002 \\
Ln(M $)$ & 8.796366 & 0.002709 & 0.897685 & 0.000330 \\
Ln(LQR) & 6.689769 & 8.349406 & 2.437002 & 0.000078 \\
Ln(CRR) & 5.743547 & 0.003752 & 1.797808 & 0.000024
\end{tabular}




\begin{tabular}{llll}
\hline R-squared & 0.581224 & Mean dependent var. & 153.3286 \\
Adjusted R-squared & 0.528143 & S.D. dependent var. & 37.83676 \\
S.E. of regression & 16.47386 & Akaike info criterion & 13273.59 \\
Sum squared resid & 40213.10 & Schwarz criterion & 124.6039 \\
Log likelihood & -122.673 & F-statistic & 7.947685 \\
Durbin-Watson stat & 1.760364 & Prob(F-statistic) & 0.000000 \\
\hline \hline
\end{tabular}

Source: Author's computation with the use of E-view 9.1

The results on table 4 show that error-correction coefficient $(-0.832583)$ is statistically significant and has a negative sign, which confirms a necessary condition for the variables to be co-integrated. Hence, there is a long-run equilibrium effect on monetary policy and the private sector economy in Nigeria; and, the result confirms that about $73 \%$ short-run adjustment speed from long-run disequilibrium. Hence, the coefficient of determination $\left(\mathrm{R}^{2}=0.650124\right)$ indicates that about $65 \%$ of the variations in private sector growth can be explained by changes in monetary policy variables $\left(\mathrm{M}_{2}, \mathrm{LQR}, \mathrm{CRR}\right)$ in Nigeria. This implies that a significant portion of private sector growth is explained by monetary policy variables. The F-Statistics of (7.947685) which is significant at 5\% confirms the impact of monetary policy on private sector growth in Nigeria; for the period 1990-2018. The influence of the explanatory variables on the dependent variable is statistically significant and this is also confirmed by the F-probability which is statistically zero.

\section{Test of Hypotheses}

Ho1: Broad money supply has no significant effect private sector output in Nigeria. Decision Criteria, Level of significance ( $\alpha$ ): 0.05 (5\%). Decision Rule: Reject $\mathrm{H}_{0}$ : If $\mathrm{p}$ - value $<0.05$ and accept $\mathrm{H}_{0}$ if $\mathrm{p}$ - value $>0.05$. The results on table 4 show that monetary policy rate has a tstatistic of 0.897685 with a probability of 0.000330 which is lower than the level of significance of 0.05 , which means, its effect is statistically significant. The null hypothesis is, thus, rejected. Thus, monetary policy rate has a significant effect on private sector output in Nigeria. $\mathbf{H o}_{2}$ : Liquidity ratio has no significant effect on private sector output in Nigeria. Decision Rule: Reject $\mathrm{H}_{0}$ : If $\mathrm{p}$ - value $<0.05$ and accept $\mathrm{H}_{0}$ if $\mathrm{p}$ - value $>0.05$. The results on table 4 show that liquidity ratio has a t-statistic of 2.437002 with a probability of 0.000078 which is lower than the level of significance of 0.05 , which means, hence, its effect is statistically significant. The null hypothesis is, therefore, rejected. Thus, liquidity ratio has a significant effect on private sector output in Nigeria. Ho3: Credit ratio has no significant effect on private sector output in Nigeria. Decision Rule, Reject $\mathrm{H}_{0}$ : If $\mathrm{p}$ - value $<0.05$ and accept $\mathrm{H}_{0}$ if $\mathrm{p}$ - value $>0.05$, The results on table 4 show that credit ratio has a t-statistic of 1.797808 with a probability of 0.000024 which is lower than the level of significance of 0.05 , which means, hence, its effect is statistically significant. The null hypothesis is therefore rejected. Hence, credit ratio has a significant effect on private sector output in Nigeria. 


\section{CONCLUSION AND RECOMMENDATIONS}

The study concluded that monetary policy has a significant impact on private sector performance in Nigeria. This is consistent with the work of Chileke (2020) which revealed that monetary policy has a significant effect on private sector-led economy in Nigeria. This implies that monetary policy variables are statistically significant in explaining growth and development of the private sector in Nigeria. This could be as a result of consistent monetary policies which is capable of influencing the private sector-led economy positively. The study recommends that strong macro-economic policies such as (monetary and fiscal) should be employed to maintain and stabilize the economy. CBN should lay down strict prudential guidelines to stabilize and strengthen the private sector led-economy. Government and policy makers should formulate policies that will increase the flow of investable funds and improves the capacity of private led-economy in Nigeria.

\section{Contribution to Knowledge}

The study was able to modify the model, expand the existing literature, empirical review, geographical spread and updated data that will enable researchers and scholars to use it for further studies. The study concludes that monetary policy has significantly impacted on private sector growth in Nigeria.

\section{REFERENCES}

Agbaje, D. F (2018). Effect of monetary policy on economic growth in Nigeria. International Journal of Accounting, Finance and Management,31(6),175-188.

Ajie, G. N. \& Azuna, D (2018). Monetary policy and bank performance in Nigeria: A cointegration investigation. African Journal of Finance and Research, 23(11),67-84.

Aliyu, Q \& Daida, G. (2018). An empirical investigation of monetary policy on foreign trade in Nigeria. Journal of Economic Development Research and Investment, 45(23), 175192.

Andabai, Priye W (2016). Empirical investigation on the relationship between bank credit and private sector growth in Nigeria. An unpublished $\mathrm{PhD}$ thesis submitted to the department of banking and finance. School of PostGraduate Studies, Anambra State University, Nigeria.

Andabai, Priye W, Ikeora, Joseph J. E \& Anah, S. A (2019). Impact of monetary policy on economic growth in Nigeria. Management and Human Resource Research Journal, 8(3), 1-6.

Andabai, Priye W. (2017). Private sector development and economic growth in Nigeria. International Journal of Advanced Research in Statistics, Management and Finance, 2(1); 15-25.

Arestis, P. ; Demetriades, G \& Luintel, G (2017). Financial development and economic growth: The role of stock markets. Global Journal of finance and Banking Research, 34(11),116-141.

Arnold, I.J.M., Kool, N \& Raabe, S (2018). Bank lending and its effects on credit demand and monetary policy in Germany. Deutsche Bundesbank Discussion Paper Series No. 48 . 
Bellow, F. (2018). Monetary policy and Banking sector reforms in the Nigerian economy. Journal of Finance, Management and Economics Research, 25(12), 147-157

Bellowa, D \& Amelant, G (2017). Credit Issues: Empirical evidence on Gambia, macrofinancial Nexus. IMF Working Papers No. WP/23/234

Bencivenga.V. R. (2018). Financial intermediation and endogenous growth. Review of Economic and Management Studies, 58(34), 195-209.

Bernite, B. S. \& Benson, A. R. (2018). Impact of monetary transmission on the Nigerian economy. European Journal of Financial Economics and Research, 34(12), 347-367.

Blundell-Wignall, A (2016). Bank Lending Puzzles: Business Models and the Responsiveness to Policy. OECD Journal, 1, 1-25.

Gambacorta, L (2003). The Italian banking system and monetary policy transmission: Evidence from bank-level data, In Angeloni, I., Kashyap, A., \& Mojon, B., editors, Monetary

Ibenta, Steve, N. O. (2012). Research Monograph: Guidelines for Seminar Papers, Theses \& Project Reports. 22-28 Regina Caeli Rd, Awka, Anambra State.

Oguda, F \& Chinda, O (2018). Monetary policy and credit condition: Evidence from the money market. International Journal of Finance and Banking Research,25(10), 166183.

Oke, F. (2017). Effect of interest rate on the performance of Nigerian deposit money banks. Global Journal of finance and Management Studies,21(11), 134 - 143.

Okorie, O. V \& Enzue, C (2018). Capital market and industrial sector development in Nigeria: A theoretical Analysis. Journal of Emerging Trends in Economics and Management Research, 4(1), 120-132.

Ougaku, B \& Oparanta, H (2018). Monetary policy and real sector performance in Nigeria. Research Journal of Business, Economics and Finance.6(23), 123-139 


\section{APPENDIX}

Private Sector Output (PSO), Broad Money Supply (M2), Credit Ratio (CRR), Liquidity Ratio (LQR) in Nigeria from 1995-2021

\begin{tabular}{|c|c|c|c|c|}
\hline YEAR & $\begin{array}{c}\text { PSO } \\
\text { (\#'Billion) }\end{array}$ & $\begin{array}{c}\mathrm{M}_{2} \\
\text { (\#' Billion) }\end{array}$ & $\begin{array}{l}\text { CRR } \\
(\%)\end{array}$ & $\begin{array}{c}\mathrm{LQR} \\
(\%)\end{array}$ \\
\hline 1990 & 253.9 & 52.86 & 11.07 & 25.50 \\
\hline 1991 & 453.9 & 75.40 & 9.43 & 20.01 \\
\hline 1992 & 745.6 & 111.11 & 9.16 & 29.80 \\
\hline 1993 & 896.4 & 165.34 & 7.50 & 18.32 \\
\hline 1994 & $1,099.0$ & 230.29 & 9.97 & 21.00 \\
\hline 1995 & $2,417.3$ & 289.09 & 3.40 & 20.18 \\
\hline 1996 & $3,401.7$ & 345.85 & 6.70 & 19.74 \\
\hline 1997 & $3,474.6$ & 413.28 & 8.40 & 13.54 \\
\hline 1998 & $3,154.3$ & 488.15 & 10.90 & 18.29 \\
\hline 1999 & $3,727.0$ & 628.95 & 16.90 & 21.32 \\
\hline 2000 & $5,618.7$ & 878.46 & 22.70 & 17.98 \\
\hline 2001 & $5,353.4$ & $1,269.32$ & 27.70 & 18.29 \\
\hline 2002 & $6,158.2$ & $1,505.96$ & 62.00 & 24.85 \\
\hline 2003 & $7,946.8$ & $1,952.92$ & 77.80 & 20.71 \\
\hline 2004 & $8,688.5$ & $2,131.82$ & 125.30 & 19.18 \\
\hline 2005 & $11,069.5$ & $2,637.91$ & 139.70 & 17.95 \\
\hline 2006 & $13,817.4$ & $3,797.91$ & 152.30 & 17.28 \\
\hline 2007 & $15,321.9$ & $5,127.40$ & 158.00 & 15.94 \\
\hline 2008 & $18,221.3$ & $8,008.20$ & 101.10 & 15.14 \\
\hline 2009 & $17,820.4$ & $9,419.92$ & 206.50 & 18.99 \\
\hline 2010 & $26,116.8$ & $11,034.94$ & 148.10 & 17.59 \\
\hline 2011 & $28,324.0$ & $12,172.49$ & 150.70 & 16.02 \\
\hline 2012 & $30,053.1$ & $13,895.39$ & 87.00 & 16.79 \\
\hline 2013 & $30,278.2$ & $15,158.62$ & 95.60 & 17.02 \\
\hline 2014 & $49,097.94$ & $17,680.52$ & 770.00 & 16.55 \\
\hline 2015 & $37,576.474$ & $19,772.87$ & 133.86 & 12.00 \\
\hline 2016 & $38,761.225$ & $19,988.37$ & 227.0 & 15.00 \\
\hline 2017 & $38,676.352$ & $19,084.64$ & 201.23 & 15.00 \\
\hline 2018 & $39,526.716$ & $105,364.73$ & 143.34 & 17.00 \\
\hline 2019 & $39,632.543$ & $123,231.35$ & 152.31 & 18.00 \\
\hline
\end{tabular}

Source: Central Bank of Nigeria Statistical Bulletin,2019. 